Chir Gastroenterol 1996;12:I-VI

\title{
Inhalt - Contents, Vol. 12, 1997
}

\section{Inhalt Band 12,1996}

Chirurgische $3 / 8$ Gastroenteroloáe

mit interdisziplinären Gesprächen $\mathrm{Cy}$

Editorials

15 Interventionelle Maßnahmen in der Gastroenterologie

Betzler, M. (Essen)

289 Postoperativer Ernährungsaufbau

Klar, E. (Heidelberg)

3179 Die chronische Pankreatitis im Brennpunkt zwischen

pathophysiologischem Verständnis und technischen Möglichkeiten

Horn, J. (München)

4276 Vorwort

Paquet, K.-J. (Bad Kissingen); Sauerbruch, T. (Bonn)

Hauptthema

16 Endoskopische Therapie von Stenosen im Gastrointestinaltrakt

Grund, K. E.; Zindel, C; Storek, D. (Tubingen)

115 Endoskopische Behandlung von Fisteln am

Gastrointestinaltrakt

Salm, R.; Pauly, E. (Donaueschingen)

120 Die Gastrostomie -

interventionelle und laparoskopische Techniken

Ditfurth, B. von (Kassel)

126 Die Behandlung von Pankreaspseudozysten unter

Berücksichtigung interventioneller und chirurgischer Verfahren

Markus, P. M.; Heise, J.; Münke, H.; Becker, H. (Göttingen)

132 Interventionelle Techniken am Gallenwegssystem

Scheurlen, Ch.; Sauerbruch, T. (Bonn)

138 Interventionelle Techniken am Pankreasgangsystem

Riemann, J. F.; Bregenzer, N.; Maier, M.; Benz, C; Martin, W. R. (Ludwigshafen)

143 Endoskopische Therapie der Blutung im oberen

Gastrointestinaltrakt

Manegold, B. C; Meier-Willersen, H.-J. (Mannheim)

290 Besonderheiten der postoperativen Ernährung bei

Leberinsuffízienz

Leweling, H.; Holm, E. (Heidelberg)

2100 Pro und Kontra der parenteralen Ernährung in der komplizierten postoperativen Phase bei Sepsis

Jauch, K.-W.; Herrmann, A. (Regensburg) 
2104 Pro und Kontra der enteralen Ernährung in der komplizierten postoperativen Phase bei Sepsis

Kemen, M. (Bochum)

2108 Postoperative parenterale Ernährung:

Hypokalorisches Konzept nach mittleren Eingriffen

Behrendt, W.; Raumanns, J.; Breuer, R. (Aachen)

2112 Postoperative Ernährung bei Patienten mit renaler Insuffîzienz

Druml, W. (Wien)

2119 Die Rolle von Zuckeraustauschstoffen, insbesondere

Xylit, in der postoperativen Ernährung

Georgieff, M.; Schricker, Th. (Ulm)

3182 Pankreatitis: Pathologische Anatomie

Meister, P. (München)

3188 Chronische Pankreatitis: Organfunktion und Krank-heitsverlauf

Lankisch, G P. (Lüneburg)

3192 Der Stellenwert der bildgebenden Verfahren bei der Einschätzung der chronischen

Pankreatitis

Pfeifer, K.-J.; Mangel, E. (München)

3198 Pathomorphologische Überlegungen für die operative Therapieplanung bei der chronischen Pankreatitis

Horn, J.; Kremser, H. (München)

3206 Konservative und interventionelle Therapiemaß-nahmen bei der chronischen Pankreatitis

Schneider, H. T. (Erlangen); Löhr, J.-M. (Rostock); Ell, C; Hahn, E. G. (Erlangen)

3214 Operative Therapie der chronischen Pankreatitis: Technik und Langzeitergebnisse

Reber, P. U.; Friess, H.; Büchler, M. W. (Bern)

3222 Chronische Pankreatitis mit entzündlicher Pankreas-kopfvergrößerung - Früh- und

Spätergebnisse nach duodenumerhaltender Pankreaskopfresektion

Schoenberg, M. H.; Schlosser, W.; Beger , H. G (Ulm)

3228 Differentialtherapie der Pankreas-assoziierten Zyste

Gebhardt, Ch. (Nürnberg)

3232 Die chronische Pankreatitis - eine Präkanzerose?

Wandl, U. B. (München)

4278 Systemische hämodynamische Veränderungen beim

Pfortaderdruck

Brensing, K. A.; Heller, J.; Sauerbruch, T. (Bonn)

4283 Diagnostik von Osophagusvarizen, Fundusvarizen und portaler Hypertension

Grüne, S.; Gmeinwieser, J.; Holstege, A. (Regensburg)

4289 Therapie der akuten Blutung von Ösophagus- und Magenvarizen

Mühldorfer, S. M.; Ell, C. (Erlangen-Nürnberg)

4295 Medikamentöse Behandlung der portalen Hypertension

Gerbes, A. L. (München)

4299 Indikationen und Erfahrungen mit TIPSS bei Kompli-kationen der portalen Hypertension

Richter, G. M.; Roeren, Th.; Brado, M.; Theilmann, L.; Sauer, P.; Kauffmann, P. (Heidelberg)

KÄRGER

(C) 1996 S. Karger GmbH, Freiburg 
Fax (0761) 4520714

http://www.karger.ch/journals/cga/cgades.htm

4308 Ösophagusvarizen: Prophylaxe der Rezidivblutung -Ligatur

Brand, B.; Seiz, U.; Binmoeller, K. F.; Bohnacker, S.; Thonke, F.; Soehendra, N. (Hamburg)

4314 Zum Stellenwert der Sperr- und Shuntoperationen bei der Therapie der rezidivierenden

Ösophagus-und/oder Magenvarizenblutung des Zirrhotikers

Paquet, K.-J. (Bad Kissingen)

4321 Lebertransplantation und portale Hypertension

Wolff, M.; Hirner, A. (Bonn)

4326 Therapie des Aszites

Frick, E.; Schölmerich, J. (Regensburg)

4338 Therapie der hepatischen Enzephalopathie

Wettstein, M.; Häussinger, D. (Düsseldorf)

4344 Einfluß des Pfortaderhochdrucks auf die Leberfunktion

Krähenbühl, L.; Büchler, M. W. (Bern)

Interdisziplinäres Gespräch

153 Interventionelle Maßnahmen in der gastroentero-logischen Chirurgie und Gastroenterologie

Schreiber, H. W. (Hamburg) (Gesprächsleiter)

3236 Chronische Pankreatitis

Izbicki, J. R. (Hamburg) (Gesprächsleiter)

4350 Offene und kontroverse Fragen zur portalen

Hypertension

Gangl, A. (Wien) (Gesprächsleiter)

Originalarbeiten

162 Tages- und ambulante Chirurgie -das Lund-Modell aus Schweden

Holstein, Ch. S. von; Lundgren, P. O.; Wallin, E.; Ihse, I. (Lund)

166 Hypertriglyzeridämie und akute Pankreatitis

Lechleitner, ML; Ladner, E.; Seyr, M.; Hoppichler, F.; Föger, B.; Hackl, J. M. (Innsbruck)

2126 Operative Therapie der Crohnschen Erkrankung:

Klassische Indikationen - neue Entwicklungen

Schneider, M.; Schmidt, E. (Würzburg)

2 132Hämobilie

Wu Zaide; Wu Yaqun (Wuhan)

2136 Strahlentherapie beim Rektumkarzinom: Prä- und/oder postoperativ?

Greiner, R. H. (Bern)

2146 Adultes polyzystisches Leberleiden: Resultate und

Verlauf nach chirurgischer Resektions-Fenestrations-Behandlung

Holzinger, F.; Baer, H. U.; Maurer, Ch.; Büchler, M. W. (Bern)

2153 Zytokinprofil beim experimentellen Gallenverschluß

Kyzer, S.; Myslovaty, B. (Patah Tiqva); Fishman, P. (Tel Aviv); Gelber, E. (Patah Tiqva);

Zigelman, R.; Rudnicki, C. (Tel Aviv); Chaimoff, C. (Patha Tiqva)

3244 Die Chirurgie des kleinen hepatozellularen Karzinoms

in China

Tang, Z. Y.; Yu, Y. Q.; Zhou, X. D.; Yang, B. H., Lin, Z. Y. (Shanghai)

3250 Lebersegmentresektion bei 120 Patienten

Chen, X. P.; Zaide, W.; Fazu, Q. (Tongji) 
3253 Die einmalige Spülbehandlung im standardisierten

Tiermodell zur chronischen abszedierenden Peritonitis

Woltmann, A.; Schult, M.; Kattenbeck, K.; Broil, R. (Lübeck); Gatermann, S. (Mainz); Lebeau, A. (München); Bruch, H.-P. (Lübeck)

$4 \quad 358$ Adjuvante Therapie der Peritonitis und ihren septischen Verlaufsformen mit Taurolidin - eine prospektive randomisierte Studie

Reith, H. B. (Bochum); Dittrich, H. (Rendsburg); Haarmann, W.; Smektala, R.; Dohle, J.;

Kozuschek, W. (Bochum)

Minimal invasive Chirurgie

171 Laparoskopische Eingriffe beim Leistenbruch mit

besonderer Berücksichtigung des Rezidivs

Birth, M.; Eichler, M.; Weiser, H.-F. (Rotenburg)

Prä- und postoperative Therapie

177 Editorial: Immunglobuline in der perioperativen

Therapie

Probst, M. (Lemgo)

Mit einer Mitteilung der Herausgeber

2158 Funktionsdiagnostik des oberen Gastrointestinaltrakts:

2. Magen, 3. Pankreas

Reith, H. B. (Würzburg) (Gesprächsleiter)

3258 Funktionsdiagnostik des Dunn- und Dickdarms sowie

des Sphinkterapparates

Reith, H. B. (Würzburg) (Gesprächsleiter)

Industrieforum

2164 Juristische Aspekte bei der Herstellung von Mischin-fusionen in Kliniken

Wartensleben, H. (Stolberg)

Supplement 1

Pankreastransplantation

Busing, M. (Bochum); Hopt, U. T. (Rostock); Kozuschek, W. (Bochum) (Hrsg.)

Supplement 2

Minimal invasive Chirurgie

Lotz, G. W.; Stahlschmidt, M. (Mainz) (Hrsg.)

Contents Vol. 12,1996

Chirurgische

Editorials

15 Interventional Measures in the Gastroenterology

Betzler, M. (Essen)

289 Postoperative Nutrition

Klar, E. (Heidelberg)

3179 Chronic Pancreatitis in the Focus between Pathophy-

siologic Understanding and Technical Possibilities

Horn, J. (München)

4276 Preface

Paquet, K.-J. (Bad Kissingen); Sauerbruch, T. (Bonn)

Main Theme

16 Endoscopic Therapy of Stenoses in the Gastrointestinal Tract 
Grund, K. E.; Zindel, C; Storek, D. (Tubingen)

115 Endoscopic Treatment of Fistulae in the Gastrointestinal Tract

Salm, R.; Pauly, E. (Donaueschingen)

120 Gastrostomy - Interventional and Laparoscopic

Techniques

Ditfurth, B. von (Kassel)

126 Treatment of Pancreatic Pseudocysts Basing on Interventional and Surgical Procedures

Markus, P. M; Heise, J.; Münke, H.; Becker, H. (Göttingen)

132 Interventional Techniques on the Bile Duct System

Scheurlen, Ch.; Sauerbruch, T. (Bonn)

138 Interventional Techniques Concerning the Pancreatic Duct System

Riemann, J. F.; Bregenzer, N.; Maier, M.; Benz, C; Martin, W. R. (Ludwigshafen)

143 Endoscopic Therapy of Bleeding in the Upper

Gastrointestinal Tract

Manegold, B. C; Meier-Willersen, H.-J. (Mannheim)

290 Postoperative Nutrition Adapted to Hepatic Failure

Leweling, H.; Holm, E. (Heidelberg)

2100 The Pros and Cons of Parenteral Nutrition in the Complicated Postoperative Course with Sepsis

Jauch, K.-W.; Herrmann, A. (Regensburg)

2104 The Pros and Cons of Enteral Nutrition in the Complicated Postoperative Course with Sepsis

Kemen, M. (Bochum)

2108 Postoperative Parenteral Nutrition: Hypocaloric Concept following Moderate Surgical Interventions

Behrendt, W.; Raumanns, J.; Breuer, R. (Aachen)

2112 Postoperative Nutrition in Patients with Renal Failure

Druml, W. (Wien)

2119 The Role of Sugar Replacement Substances,

Especially Xylit, in Postoperative Nutrition

Georgieff, M.; Schricker, Th. (Ulm)

3182 Pancreatitis: Pathological Anatomy

Meister, P. (München)

3188 Chronic Pancreatitis: Organ Function and Course of

Disease

Lankisch, G. P. (Lüneburg)

3192 The Significance of Diagnostic Imaging in the Evaluation of the Chronic Pancreatitis

Pfeifer, K.-J.; Mangel, E. (München)

3198 Pathomorphological Conditions for Surgical Management in Chronic Pancreatitis

Horn, J.; Kremser, H. (München)

3206 Conservative and Interventional Therapeutic Measures in Chronic Pancreatitis

Schneider, H. T. (Erlangen); Löhr, J.-M. (Rostock); Ell, C; Hahn, E. G. (Erlangen)

3214 Surgical Treatment of Chronic Pancreatitis: Technique and Long-Term Results

Reber, P. U.; Friess, H.; Büchler, M. W. (Bern)

3222 Chronic Pancreatitis with an Inflammatory Pancreatic Head Tumor - Indication, Surgical

Technique, and Outcome of the Duodenum-Preserving Resection of the Head of the Pancreas 
Schoenberg, M. H.; Schlosser, W.; Beger, H. G. (Ulm)

3228 Differential Therapy of the Pancreatic-Associated Cyst

Gebhardt, Ch. (Nürnberg)

3232 Chronic Pancreatitis - a Precancerous Stage?

Wandl, U. B. (München)

4278 Systemic Hemodynamic Change in Portal Hypertension

Brensing, K. A.; Heller, J.; Sauerbruch, T. (Bonn)

4283 Diagnostics of Esophageal Varices, Gastric Varices, and Portal Hypertension

Grüne, S.; Gmeinwieser, J.; Holstege, A. (Regensburg)

4289 Therapy of Acute Bleeding of Esophageal and Gastric

Varices

Mühldorfer, S. M.; Ell, C. (Erlangen-Nürnberg)

4295 Pharmacological Treatment of Portal Hypertension

Gerbes, A. L. (München)

4299 Indications and Experience with the TIPSS in

Complications in Patients with Portal Hypertension

Richter, G. M.; Roeren, Th.; Brado, M.; Theilmann, L.; Sauer, P.; Kauffmann, P. (Heidelberg)

4308 Esophageal Varices: Prevention of Recurrent

Bleeding - Band Ligation

Brand, B.; Seiz, U.; Binmoeller, K. F.; Bohnacker, S.; Thonke, F.; Soehendra, N. (Hamburg)

\section{KARGEIl}

(C) 1996 S. Karger GmbH, Freiburg

Fax (0761) 4520714

http://www.karger.ch/journals/cga/cgades.htin

4314 Value of Devascularisations and Shunt Procedures in the Therapy of the Recurrent

Bleeding from Eso-phagogastric Varices in Patients with Liver Cirrhosis

Paquet, K.-J. (Bad Kissingen)

4321 Liver Transplantation and Portal Hypertension

Wolff, M.; Hirner, A. (Bonn)

4326 Therapy of Patients with Ascites

Frick, E.; Schölmerich, J. (Regensburg)

4338 Therapy of Hepatic Encephalopathy

Wettstein, M.; Häussinger, D. (Düsseldorf)

4344 Influence of the Portal Hypertension on Liver Function

Krähenbühl, L.; Büchler, M. W. (Bern)

Interdisziplinary Discussion

153 Interventional Measures in the Gastroenterological

Surgery and Gastroenterology

Schreiber, H. W. (Hamburg) (Discussion Leader)

3236 Chronic Pancreatitis

Izbicki, J. R. (Hamburg) (Discussion Leader)

4350 Open and Controversial Questions to the Portal

Hypertension

Gangl, A. (Wien) (Discussion Leader)

Original Articles 
162 Day and Short Stay Surgery -the Lund Model from Sweden

Holstein, Ch. S. von; Lundgren, P. O.; Wallin, E.; Ihse, I. (Lund)

166 Hypertriglyceridemia and Acute Pancreatitis

Lechleitner, M.; Ladner, E.; Seyr, M.; Hoppichler, F.; Föger, B.; Hackl, J. M. (Innsbruck)

2126 Operative Therapy of Crohn's Disease:

Classical Indications - New Developments

Schneider, M.; Schmidt, E. (Würzburg)

2132 Hemobilia

Wu Zaide; Wu Yaqun (Wuhan)

2136 Radiation Therapy for Rectal Cancer:

Pre- and/or Postoperatively?

Greiner, R. H. (Bern)

2146 Adult Poly cystic Liver Disease: Results and Clinical Experience after Surgical Treatment with Resection/Fenestration

Holzinger, F.; Baer, H. U.; Maurer, Ch.; Büchler, M. W. (Bern)

2153 Cytokines Profile in Experimental Biliary Obstruction

Kyzer, S.; Myslovaty, B. (Patah Tiqva); Fishman, P. (Tel Aviv); Gelber, E. (Patah Tiqva);

Zigelman, R.; Rudnicki, C. (Tel Aviv); Chaimoff, C. (Patha Tiqva)

3244 Surgery of the Small Hepatocellular Carcinoma in China

Tang, Z. Y.; Yu, Y. Q.; Zhou, X. D.; Yang, B. H.; Lin, Z. Y. (Shanghai)

3250 Hepatic Segmentectomy in 120 Patients

Chen, X. P.; Zaide, W.; Fazu, Q. (Tongji)

3253 The Single Lavage in a Standardised Animal Model

for Chronic Abscess-Forming Peritonitis

Woltmann, A.; Schult, ML; Kattenbeck, K.; Broil, R. (Lübeck); Gatermann, S. (Mainz); Lebeau, A. (München); Bruch, H.-P. (Lübeck)

4358 The Influence of Taurolidin in the Treatment of

Severe Intraabdominal Infections and Septic Patients - a Prospective Randomized Study

Reith, H. B. (Bochum); Dittrich, H. (Rendsburg); Haarmann, W.; Smektala, R.; Dohle, J.;

Kozuschek, W. (Bochum)

Minimally Invasive Therapy

171 Laparoscopic Hernia Repair - Especially Considering Recurrences

Birth, M.; Eichler, M.; Weiser, H.-F. (Rotenburg)

Pre- and Postoperative Therapy

177 Editorial: Immunoglobulins in the Perioperative

Therapy

Probst, M. (Lemgo)

With an Information of the Editors

2158 Functional Diagnostic of the Upper Gastrointestinal

Tract: 2. Stomach, 3. Pancreas

Reith, H. B. (Würzburg) (Discussion Leader)

3258 Functional Diagnostic of the Small and Large Intestine

and of the Sphincter

Reith, H. B. (Würzburg) (Discussion Leader) ‘

Industrial Forum

2164 Juridical Aspects in the Preparation of Mixed Infusions in Hospitals 
Wartensleben, H. (Stolberg)

Supplement 1

Pankreastransplantation

Busing, M. (Bochum); Hopt, U. T. (Rostock); Kozuschek, W. (Bochum) (Hrsg.)

Supplement 2

Minimal invasive Chirurgie

Lotz, G. W.; Stahlschmidt, M. (Mainz) (Hrsg.)

VI 